\title{
Beyond PES and REDD+: Costa Rica on the way to climate-smart landscape management?
}

\author{
$\underline{\text { Linda Wallbott }}^{1}$, Giuseppina Siciliano $^{2}$ and Markus Lederer ${ }^{1}$
}

\begin{abstract}
Costa Rica has a strong international reputation for conservation and sustainable management of forests, including through its national payments for environmental services (PES) system and reducing emissions from deforestation and forest degradation (REDD+). However, to be able to take those achievements to the next level, new approaches need to be developed that integrate agriculture and environmental politics, e.g., to foster climate-smart landscape management. This would be in line with the idea of a green transformation as a necessary contribution to bring human social-ecological action back within planetary boundaries. We start from a general conceptualization of a green transformation and its potential drivers, then analyze the basis and prospects for such developments by providing a review of the country's forest politics, including a mapping of relevant stakeholders that have been influential in designing and implementing the national PES and REDD+ approaches. Based on original empirical analysis that was conducted throughout 2017, we further analyze recent institutional developments of setting up a cross-sectoral policy for agriculture and environment as part of a broader landscape management approach, including the opportunities and challenges that might arise with a view to realizing this idea on the ground.
\end{abstract}

Key Words: climate-smart agriculture; Costa Rica; landscape management; payments for environmental services (PES); reducing emissions from deforestation and forest degradation ( REDD+)

\section{INTRODUCTION}

Costa Rica has a strong legacy in halting deforestation, and its national system on payments for environmental services (PES) has been internationally recognized for being the most successful of its kind. However, PES and the related forest policy "reducing emissions from deforestation and forest degradation" (REDD+) have also been considered rather low hanging fruits that could be realized without much effort but that are ultimately, and when considered in isolation, insufficient to comprehensively tackle ecological, social, and economic pressures on ecosystem goods and services like timber, fibre, water, and food. Costa Rica, nevertheless, committed to restore another 1 million hectares of forest as part of the international action program Bonn Challenge (http://www.bonnchallenge.org/content/challenge) in 2012. Because this will not be achieved through forest-based measures (e.g., REDD+) alone, a broader focus on land use, and in line with international developments (Nielsen 2016, Turnhout et al. 2017), has recently been adopted. Thus, academics and practitioners alike have come to acknowledge that the next step for achieving sustainable land use in Costa Rica will require the transformation of cultural and productive lands, and include the use of new knowledge, technology, and sustainable business models.

In policy terms, this idea of a new agro-environmental agenda gained institutional legitimacy through the country's policy for agriculture and environment (Política Agroambiental), which has the potential to serve as an umbrella framework for integrating the isolated processes of REDD+, National Appropriate Mitigation Action (NAMA) livestock/cattle, NAMA coffee, nationally determined contributions, and other climate change mitigation and adaptation programs. The policy is supposed to initiate rehabilitation and restoration of the provision of ecosystem services without triggering a competition of land uses. Corresponding stakeholder processes should include negotiations between different interest groups, the establishment of compensation mechanisms but also the creation of markets via certification schemes, and the reconciliation of knowledgeintensive technologies. The crucial relevance of the approach was further emphasized in November 2016, when the Interministerial Commission of the Ministry of Agriculture and Livestock and the Ministry of the Environment and Energy decided to develop an action plan to implement the policy.

We analyze how these Costa Rican developments toward a new sustainable pathway of land-use management have come about and evaluate the challenges and opportunities in implementing them. We argue that, whereas the development of the national PES and REDD+ policies have been characterized by strong institutional capacity, further guidance is required to put an integrated landscape-management approach into practice. Our research is based on an interdisciplinary approach that features analyses of primary and secondary literature, participant observation, and expert interviews in Costa Rica between March and June of 2017.

\section{ANALYTICAL FRAMEWORK}

Landscapes are terrestrial ecosystems "with a specific geomorphology, climate, soil and vegetation pattern together with the associated fauna" (Gertenbach 1983:9). They function as carbon stocks and are important for the global carbon cycle (IPCC 2000). However, landscapes change constantly and are increasingly experiencing pressure from climate change and (unfavorable) land-use practices (Lambin et al. 2001). In this context, direct land-use changes can be differentiated from indirect land-use changes (Lapola et al. 2010). The former encompasses the replacement of native habitats, e.g., through the introduction of new crops in food and livestock areas. Indirect land-use change instead refers to the anew creation of agricultural land in formerly natural ecosystems fostered by economic incentives for farmers. These incentives stem from price changes

${ }^{1}$ Technische Universität Darmstadt, Germany, ${ }^{2}$ Centre for Development, Environment and Policy (CeDEP), School of Oriental and African Studies (SOAS), University of London, UK 
as the availability of agricultural products has decreased, e.g., due to the introduction of biofuels that pushed aside traditional cultivation. Hence, new cropland for the previously replaced agricultural products is created, possibly by employing means of forest conversion or deforestation and accompanied by further greenhouse gas emissions and fragmentation of space. Ultimately, indirect land-use changes are an indicator for the relative valorization of land-based products, goods, and services in a globalized economy, as well as for the value that local stewards attribute to different types of land cover. Thus, land-use change is closely linked to rivalry of different types of land use. This distinction of different forms of land-use change is a valuable starting point to capture the drivers and consequences of establishing (new) landscape-management approaches.

Such transitions are usually influenced by policy design and political action. Thus, government policies can accelerate or hamper the sustainability of land-use practices. To capture the kind of modifications of policy and action that render ecosystem governance more sustainable in the sense of bringing human action (back) within the planetary boundaries (Scoones et al. 2015), the concept of "green transformations" has been established and applied as an analytical lens to understand change processes in countries of the Global South (Lederer et al. 2019). A substantial green transformation needs to respond to environmental challenges such as global climate change, natural resource depletion, air pollution, water pollution, deforestation, biodiversity loss, and others that exist at various scales (global, regional, national, local). At the same time, green transformations entail normative considerations and should be socially just and equitable. Put differently, green transformations are not only about the proliferation of new technologies or the sole introduction of market incentives as in the concept of a green economy (Lederer et al. 2019). Rather, more profound, wideranging political, social, economic, and environmental transformations are required to realize the sustainability potential of green transformations. Thus, we argue that any kind of meaningful green transformation, also when it includes the landuse sector, will not evolve as a simple and sectoral technological transition. Instead, any substantial engagement needs to comprise all contributions that go beyond the national business-as-usual scenario across the ecological, economic, and social dimensions (WBGU 2011). At the same time, we assume that the diffusion of green transformation innovations, such as those that relate to landscape management, is not merely a technical issue but a complex of social and political processes across different levels and sectors (Schmitz and Becker 2013, Lederer et al. 2019).

Drivers of green transformations have been widely discussed. They include technological, economic, and ideational drivers but, with a focus on change agents (WBGU 2011), also proactive public actors, notably governments and bureaucracies (Lederer et al. 2019). Instruments that such state agents have at their disposal include financial signals, regulation, or the facilitation of communication. In more detail, we might thus expect taxing pollution and accounting for negative externalities over provision of research funding, infrastructure investments, sustainable procurement to cutting harmful subsidies, and nudging regulations that favor green practices over business as usual approaches. The set-up of institutional spaces in which relevant actors can come together to discuss challenges, opportunities, and possible ways forward in policy reform can be an enabling condition to induce learning and persuasion in the interest of a green transformation.

\section{ORGANIZATION AND DEVELOPMENT OF LAND USE IN COSTA RICA: DRIVERS AND POLICIES}

Costa Rica's landscape-management system has seen four broad approaches in terms of the main strategies and instruments employed to guide environmental and forest utilization practices (see also Navarro and Thiel 2007 for a more detailed overview of the country's forest policy and legislation). The period between the early 1950 s to around 1980 focused strongly on direct regulation to protect endangered ecosystems, including the establishment of a strong protected area system $(26.9 \%$ of the country) and the set-up of land-use restrictions. However, in the 1980s it turned out that policy innovation was necessary to steer land-use changes because the country experienced high forestcover loss and one of the fastest deforestation rates in Latin America (Sánchez-Azofeifa et al. 2007), mainly because of the conversion of land into agricultural areas and pasture. In the 1980s and up until the mid-1990s forest subsidies were added to the policy portfolio such as income tax breaks, cash bonds for conservation, and subsidized credits. Between 1985 and 1998, sustainable forest management standards for tropical forest and plantation forestry were developed, and the years 1995 to 1996 witnessed the introduction of the seminal PES system as a compensation measure through provisions in the Forest Law. Further selected policy milestones of Costa Rica's landscape management have been the formulation of the National Climate Change Strategy (2008), the 2021 carbon neutrality goal (2008), the National Carbon Market (2011), the REDD+ Strategy (2010-2014), and the National Development Plan (2011-2014), which rendered environment and land-use planning as national priorities.

Today, sustainable management of the land-use sector in Costa Rica can be categorized in two main objectives: conservation and sustainable production, even though both issue areas can also overlap, e.g., in agroforestry and sustainable forest management activities (Pagiola 2008). Those outlooks for Costa Rica's landuse governance have been supported by a mixture of economic and ideational drivers and collaboration between state agencies and nonstate actors.

Conservation, particularly focusing on forests and water catchment areas, is associated with the PES program, active since 1997, as well as the REDD+ initiative for which Costa Rica is in its readiness phase and that has its national institutional base with the Ministry of the Environment and Energy. Both PES and REDD+ programs are based on a combination of different policies and practices, including a regulatory framework, an institutionalized governance and measurement system, and stakeholder consultation. Sustainable production is mainly associated with NAMAs because they have been promoted at United Nations' climate negotiations. The two NAMAs established in Costa Rica deal with the sustainable livestock/cattle management program and low carbon coffee and are executed under the auspices of the Ministry of Agriculture and Livestock. National Appropriate Mitigation Actions need to be project based with the aim to change production and processing practices in the two sectors, possibly along the whole value chain. They 
shall also incentivize private sector's investments by providing grants and loans to promote the adoption of climate-friendly technology. Pilot projects are already running in both sectors.

The PES program originated and developed from an idea of FUNDECOR, a Costa Rican nongovernmental organization founded in 1989. However, already, before the PES system was established, FUNDECOR had supported and developed sustainable development programs with farmers and other landowners, building trust and cooperation with them (expert interview on March 7, 2017), which is indicative of the institutional and ideational legacy as well as the relevance of nonstate input to Costa Rica's policy development. Also, subsequently, FUNDECOR's involvement in the development and implementation of the PES program in Costa Rica was reported to be important for the program's success and to support a positive public response because FUNDECOR encouraged farmers and other landowners to be engaged in the program (expert interview on March 7, 2017).

The financing of the Costa Rican PES program is based on tax funding and has been coined "the most successful" of its kind (GEF 2005). The World Bank, which was instrumental in triggering REDD+ development in Costa Rica (Rosendal and Schei 2014), has praised the development of the forest sector in Costa Rica because it had "evolved from an inactive sector without private organizations, technology, or specialized education, to a proactive sector with multiple organizations that lobby effectively for forest sector measures" (World Bank 2000). Today the national PES system, which is also strongly backed by the willingness of private landowners to contribute to the public good (Arriagada et al. 2015), facilitates the linkage of conservation and management of forest resources with social economic development. It allows forest owners to receive payments for protecting their forests, for growing new forests, and for managing standing forests for timber and nontimber products (MINAE 2016). To date, approximately $20 \%$ of Costa Rica's territory, 1 million hectares, has received funding through PES (MINAE 2016; expert interview on June 20, 2017). The national system of protected areas and the national PES program jointly cover $35 \%$ of the country and $70 \%$ of the forests (MINAE 2017).

Different actors are involved in the programs with a variety of responsibilities, including governmental agencies, implementers of activities, buyers as well as providers of timber and environmental services, and institutions active in education and research (FCPF 2013). Both PES and REDD+ governance are characterized by strong institutional and technical capacity. Table 1 shows the main actors involved in the PES and REDD+ with their activities and functions.

The most important institutional actor for the management of the PES and for the implementation of the REDD+ initiative at the national level is the Fondo Nacional de Financiamiento Forestal (FONAFIFO), an agency with independent legal status but with a mixed composition that encompasses representatives from the public sector; thus, it is fair to say that institutional overlaps have evolved between various agencies in relation to landuse governance in Costa Rica. The FONAFIFO involves actors from the Ministry of the Environment and Energy, the Ministry of Agriculture and Livestock, the National Banking System, and two representatives from the private sector appointed by the National Forestry Office. Others have been introduced by the
REDD+ initiative, such as the Indigenous Integrated Development Associations (ADIIs), the Biodiversity Institute, the REDD+ Secretariat, the REDD+ Executive Committee, and Sistema Nacional de Áreas de Conservación (SINAC). The REDD+ Secretariat supports the establishment of the REDD+ strategy and it is guided by the REDD+ Executive Committee, which leads the development of the program and includes representatives from key sectors. These representatives come from the following sectors: "(i) indigenous; (ii) timber industry (selected by the National Forestry Office, ONF); (iii) small-scale forest producers (selected by ONF); (iv) the National Banking System; (v) Ministry of Environment and Energy (MINAE); (vi) Ministry of Agriculture and Livestock (MAG); and (vii) civil society or owners of degraded lands.” (The REDD Desk 2018).

The main responsibility of FONAFIFO in the PES program is to manage funds for the different services provided (carbon, water, biodiversity, and scenic beauty) by approving and reallocating the funds to different beneficiaries depending on the type of ecosystem service supported. Furthermore, SINAC, which aims to promote and control conservation of forests and forest plantations in the entire national territory, plays an important role in the PES program through the selection of the priority areas to fund, the control and approval of applications, and the monitoring of program implementation through territorial inspections. Both FONAFIFO and SINAC work in close collaboration with different forestry organizations, such as FUNDECOR, independent forest regents, and forestry engineers, which provide technical and administrative support and supervision to landowners so that they may qualify for the PES program. They act as the middleman between the funds providers and beneficiaries of the program (expert interview on March 7 , 2017).

However, the PES program has also been criticized for failing to include stakeholder's perspectives and priorities (Rosendal and Schei 2014) especially those of indigenous peoples, for its complex and costly administrative procedures, for the lack of an effective monitoring system (Miranda et al. 2003, Pagiola 2008, Contraloría General de la República 2011), as well as for the exclusion of small properties (less than 50 hectares) and some of the poorest households (Porras et al. 2013). Many small landowners were not able to participate in the PES program because of the high transaction costs (World Bank 2015). This raised tensions about social justice and access among FUNDECOR, FONAFIFO, and different landowners, who required the revision of the PES program to make it not only environmentally but also socially sound (expert interview on March 7, 2017). Moreover, tensions have occurred between SINAC and indigenous communities in terms of conservation, use of the protected indigenous territories, and the implementation of the PES program. In Costa Rica, many indigenous peoples' lands overlap with protected areas. As a consequence, the protected area management regulations and the PES program ban shifting agriculture and restrict hunting, which in turn has an impact on the rights of indigenous peoples to access the forest for the collection of natural resources and traditional foods (Sylvester et al. 2016).

Among the topics under discussion related to REDD + and the new integrated landscape-management approach in Costa Rica is the question of how to find a way to enhance participation of 
Table 1. Major actors involved in payment for environmental services (PES) and reducing emissions from deforestation and forest degradation (REDD+) programs in Costa Rica.

\begin{tabular}{|c|c|}
\hline Actor & Actors' activities and functions \\
\hline \multicolumn{2}{|l|}{ Governmental agencies: } \\
\hline Ministry of the Interior and Ministry of Planning & $\begin{array}{l}\text { Governmental entities in charge of maintaining coordination and financing national } \\
\text { development programs, including PES programs. }\end{array}$ \\
\hline Ministry of Agriculture and Livestock & $\begin{array}{l}\text { Executive body responsible for agricultural production, and part of the governing body of } \\
\text { Fondo Nacional de Financiamiento Forestal (FONAFIFO). As per Executive Decree } 37352 \text { of } \\
2012 \text { of the Ministry of Environment and Energy, the Ministry of Agriculture and Livestock is a } \\
\text { member of the REDD+ Executive Committee and administers the program to develop } \\
\text { sustainable agricultural production, which helps small and medium scale producers make } \\
\text { investments to increase their income and the sustainability of their property (particularly in agro- } \\
\text { silvo-pastoral systems and protection of catchment areas). The program could contribute to the } \\
\text { national REDD+ Strategy or at least will be harmonized with it. }\end{array}$ \\
\hline Ministry of the Environment and Energy & $\begin{array}{l}\text { Executive body responsible for environmental matters in Costa Rica and part of the governing } \\
\text { body of FONAFIFO. }\end{array}$ \\
\hline Ministry of Finance & Executive body that, inter alia, is responsible for approving FONAFIFO's budget. \\
\hline National Banking System & $\begin{array}{l}\text { Representative of the governing board of FONAFIFO together with the Ministry of the } \\
\text { Environment and Energy, and the Ministry of Agriculture and Livestock. }\end{array}$ \\
\hline $\begin{array}{l}\text { Fondo Nacional de Financiamiento Forestal } \\
\text { (FONAFIFO) }\end{array}$ & $\begin{array}{l}\text { Government institution that coordinates and implements PES and is responsible for the } \\
\text { development of the REDD+ strategy. The FONAFIFO hosts the REDD+ Secretariat, in charge } \\
\text { of supporting all elements of the design and implementation of REDD+. The REDD+ } \\
\text { Executive Committee (Comité Ejecutivo REDD+) steers the REDD+ process and includes } \\
\text { representation from key sectors. }\end{array}$ \\
\hline Sistema Nacional de Áreas de Conservación (SINAC) & $\begin{array}{l}\text { Public body attached to the Ministry of Environment and Energy. It is responsible for directly } \\
\text { administering Costa Rica's protected areas and for promoting and controlling conservation and } \\
\text { sustainable natural resource management (including forest) in the entire national territory. }\end{array}$ \\
\hline
\end{tabular}

Implementers of activities:

Forestry organizations

Natural or legal persons devoted to identifying and recruiting forest owners interested in participating in PES. Their main functions are to provide technical and administrative support and supervision to landowners so that they may qualify for the PES program or for sustainable forestry management projects for wood production. Some examples are: FUNDECOR, the Association for the Sustainable Development of the Atlantic Region, Forest Development Commission of San Carlos, and independent forest regents.

Independent forest regents and forestry engineers See description above.

Buyers of timber and environmental services: Local buyers of services (carbon neutral enterprises, private environmentally sound activities, local business involved in construction), global buyers of services (Forest Carbon Partnership Facility, Carbon Fund)

Purchasers of environmental services, such as water produced by avoided deforestation, as a measure to protect the quality and flow of water necessary for their operations, either for human consumption or energy production. Forest Carbon Partnership Facility: provides incentives for emission reductions while protecting forests, conserving biodiversity, and strengthening the means of subsistence of local communities and forest-dependent indigenous peoples. Carbon neutral enterprises: purchasers of forestry emission reductions to offset their greenhouse gas stocks. Private environmentally sound activities: emissions reduction purchases, to mitigate the carbon footprint of their production activities. Local businesses: increased use of wood as a strategy to reduce their carbon footprint by substituting other materials. Hydro-electric companies for the use of water resources; fuel tax on the consumption of any crude-oil derivate.

Providers of timber and environmental services: Indigenous peoples and indigenous territories (including through Indigenous Integrated Development Associations) National Forestry Office

Private landowners

Education institutions and research: Academia and research centres

Private consultancies
Owners of land for the development of PES and REDD+ activities in indigenous territories, such as conservation of natural forests and natural regeneration, which will produce carbon rights, water, and biological diversity by avoiding deforestation.

Represents large and medium scale forestry producers and selects their representatives on the REDD+ Executive Committee. It provides advice to the Ministry of Environment and Energy on policies, legislations, and activities for sustainable forestry management, and acts as a link between the public and private sectors in terms of forest management.

Owners of land in privately owned areas for the development of activities aimed at conservation and sustainable management of natural primary and secondary forests and plantations that will produce wood and carbon rights, water, and biological diversity by avoiding deforestation.

The Tropical Agricultural Research and Higher Education Center (CATIE) and universities (such as the National University of Costa Rica). They provide support to FONAFIFO and other government institutes for the undertaking of specific research on the impacts and other related aspects of PES.

Provide support to FONAFIFO and other government institutes for the undertaking of specific research on the impacts and other related aspects of PES. 
local and indigenous communities in conservation decisions, how to provide them with greater benefits, and how to raise awareness on traditional knowledge related to conservation and sustainable use of biodiversity (expert interview on March 31, 2017). In this respect, FUNDECOR plays an important role through the establishment of the Costa Rica Green Hub and the Breathing Lab, knowledge transfer platforms created to facilitate information and knowledge exchange between institutions and different beneficiaries, including indigenous peoples, on environmental management experiences in the areas of forest governance, ecosystem services, integrated landscape management, and financial mechanisms. At the same time, FONAFIFO has established a new funding program called the Sustainable Biodiversity Fund (FONAFIFO 2018), which is to be part of the agro-environmental strategy of Costa Rica, and aims to develop additional funding mechanisms to complement current sources and to allow an expansion of the conservation area by allowing participation of those excluded by the PES program, especially small and medium landholders, landholders localized in areas with a human development index below $40 \%$, and indigenous communities. REDD+ has the potential to tackle some of the issues listed above, for example concerning the consultation and participation of different stakeholders in the decision-making process, such as indigenous communities (Baker 2014, Wallbott and Florian-Rivero 2018), small scale producers, owners of degraded lands, and poorest households (expert interview on March 31, 2017).

The main idea behind the original PES program was to protect nature and biodiversity, but REDD+ projects include a broader range of aims, such as greater economic efficiency and plantation forestry. Some argue that this shift from conservation to carbon sequestration boils down the original purpose of the PES program (Rosendal and Schei 2014, Wallbott and Florian-Rivero 2018). Other studies have found that in conjunction with the transition from net deforestation to net reforestation, Costa Rica experienced an expansion of export-oriented agricultural products that caused deforestation in the most ecologically valuable regions (Arriagada et al. 2012, Jadin et al. 2016). Thus, land-use management in Costa Rica has experienced a shift from the main priority of conservation of nature (i.e., biodiversity conservation) toward the promotion of carbon-friendly sustainable production practices, hence further relying on income generation coupled with carbon sequestration.

\section{TOWARD AN INTEGRATED LANDSCAPE MANAGEMENT APPROACH IN COSTA RICA}

Costa Rica's land-use practices reached another milestone in terms of policy formulation with the development of the Policy for Agriculture and Environment (Politica Agroambiental) at the highest political level under the vice-ministers of the Ministry of Environment and Energy and the Ministry of Agriculture and Livestock in 2015. This was mainly driven by the traditional good performance of Costa Rica in the forestry sector (so that new avenues for restoration had to be identified), FONAFIFO's previous disposition to agroforestry (in the context of REDD+), the guidance of two political actors who headed the relevant institutions and who had previously been affiliated at the same nongovernmental organization (University of Costa Rica), and by an expansive national commitment at the global level.
The Politica Agroambiental contains visions and priorities on different types of land-use changes and possible response measures, including the restoration of landscapes, and relates greenhouse gas sequestration with productivity by focusing on resource systems. Thus, major concerns are how to improve the efficiency and value chains of agricultural products, e.g., cocoa, coffee, meat, and dairy, and how to reduce emissions of carbon dioxide but also methane (expert interview June 20, 2017). This comprehensive approach should enhance livelihood conditions in rural areas, adaptive capacities to global environmental changes, quality of soil, and rehabilitation of ecosystems (Navarro and Milla 2017). The approach described above was considered to facilitate the implementation of Costa Rica's 2012 announcement to contribute one million hectares to the Bonn Challenge, which is a global initiative that was launched in 2011 and endorsed and extended in 2014. It has the aim to restore deforested and degraded land in the amount of 150 million hectares until 2020 and 350 million hectares by 2030 (IUCN 2012). The Bonn Challenge integrates normative scripts from different international institutions, namely the Convention on Biological Diversity, the UN Framework Convention on Climate Change, and the UN Conference on Sustainable Development, and is based on a forest landscape restoration approach. It thus aims "to restore ecological integrity at the same time as improving human well-being through multifunctional landscapes" (http:// www.bonnchallenge.org/content/challenge).

Related to the Bonn Challenge, and with the support of an ad hoc technical group including representatives of Bilateral Development Cooperation (GIZ), the International Union for Conservation of Nature (IUCN), and FUNDECOR (Navarro and Milla 2017), Costa Rica submitted a US\$300 million proposal on landscape restoration to the World Bank. Herein, the Ministry of Environment and Energy and the Ministry of Agriculture and Livestock developed an integrative strategy that combined the two national NAMAs (livestock/cattle, coffee) and REDD+. Furthermore, an Interministerial Commission was formed to develop the proposal and to assess options for financial interaction. The proposal, however, was rejected in late 2016 because of insufficient funding on the part of Costa Rica (expert interview on June 20, 2017).

Nevertheless, one month later, in November 2016, a mandate to develop an action plan to facilitate the implementation of the Politica Agroambiental was released. This should be under the responsibility of the Forestry Commissioner who served as the liaison officer between the Inter-Ministerial Commission, the Ad Hoc Technical Group, the World Bank, and the national government for the initial proposal on national landscape restoration. The action plan should deal with more short-term measures to prioritize action and to identify and mobilize funding sources to support communities in their landscape restoration activities, e.g., those that were heavily affected by hurricane Otto in late 2016 (expert interview on June 20, 2017). The draft action plan would then be evaluated by the Food and Agricultural Organization, which has an institutional affiliation with the Ministry of Agriculture and Livestock. Furthermore, various project proposals on long-term landscape approaches on coffee, livestock, and REDD+, which build on the rejected outline and that are to be submitted to the Green Climate Fund, that has its counterpart (focal point) in the Ministry of Environment and 
Energy, started to be developed by different national agencies (expert interview on June 20, 2017) and, thus, beyond the institutional responsibility of the Forestry Commissioner's office. In sum, both ministries are set out to play a key role in the future development of an integrated landscape-management approach, both in the short-term (projects under the action plan) and in the long-run (projects under the Green Climate Fund). The Ministry of Agriculture and Livestock can thus be expected to be more relevant in the new landscape-management strategy, as compared to the previous PES program in which it was not directly involved, because this aims to integrate conservation and rural development (expert interview on March 7, 2017).

Still, challenges for establishing effective and integrated landscape restoration in Costa Rica exist in financial, sectoral, and institutional regard. To start with, the office of the Forestry Commissioner is "a one man orchestra" (expert interview on June 20, 2017), and policy priority should go along with the allocation of more funds. However, the national tax base is thin. Furthermore, although Costa Rica has had a lot of success in the environmental area, spill-over to the agricultural sector, the second most important sector after tourism in terms of contribution to the country's GDP, is hampered by the fact that there is a lot of affected businesses. Thus, relevant actors might perceive the new approach to integrate measures across policy boundaries as a threat and not as a business opportunity. Thus, e.g., the rights of indigenous communities to participate effectively in land-use governance need to be further substantiated and also be guaranteed in broader landscape management approaches beyond REDD+ (Wallbott and Florian-Rivero 2018). At the same time, the agricultural sector must be included in the country's sustainability practices to fulfil its international commitments on landscape restoration. Hence, one challenge relates to characteristics of the resource unit in the sense that national production needs to be linked to the international market for organic agriculture. Here, differences in characteristics of niche markets can be observed. For example, international consumers of coffee or cocoa are regarded to be more selective with view to quality but also with regard to the sustainability of the product compared to consumers of dairy products and meat. In other words: the market for sustainably produced coffee and cocoa is relatively well-developed, including distribution through global business players. In contrast, markets for dairy products and meat still need to start demanding sustainable products to modify the valorization of land use and to encourage farmers to transform their conventional production practices, including, e.g., through tree plantation and improvement of pasture land. In this context, the agricultural sector needs to be familiarized with the ecosystem services approach that stems from the environmental realm, in the sense that negative externalities from all activities within one area need to be neutralized to achieve a net benefit. For this, cost-benefit analysis within the productive sector are required to calculate the financial means necessary for transition periods and the application of new technologies. Whether these cross-sectoral and multilevel tasks of managing the commons are not only sustainable, but also economically viable on a large scale is, however, an open question not only for Costa Rica but for each country that aims to pursue climate smart landscape management. Finally, institutional blindspots prevail. On the one hand, institutional interaction toward cross-sectoral landscape management was initiated between the two ministries that had previously pursued isolated efforts in which "no one was talking to each other" (expert interview on June 20, 2017). On the other hand, a joint approach toward landscape management or a reflection of diverging understandings toward the issue was not part of the debate (expert interview on June 20, 2017). This gap in interface communication might pose a challenge for the effective implementation of any future action, e.g., in terms of establishing technical monitoring of emissions from areas of abandoned pasture lands (intensive livestock production lands) because these areas could be used as secondary forests for the sustainable production of forest wood. Hence the question arises as to whether or not mitigation action should be accounted for under REDD+ (the priority of the Ministry of Environment and Energy) or NAMA livestock/cattle (priority of the Ministry of Agriculture and Livestock) to avoid double counting, entailing the question for which purpose the revenues from carbon will be utilized, e.g., forestry or agricultural practices. The latter would also include nonforest issues like support for the development of systems to enhance energy efficiency. In other words, unclear boundaries of the resource system have a potential impact on the quality of governance measures, and institutional questions have to be solved to make the system effective. Finally, a strategy that includes provisions for such an optimization process of landscape organization is still pending, possibly also due to the change in government in April 2018.

\section{CONCLUSIONS}

We analyzed Costa Rica's policy path toward integrated sustainable landscape management. We started by reviewing the main concepts shaping the country's land-use portfolio and different agro-environmental initiatives (NAMA livestock, NAMA coffee, and REDD+) that have been starting points for the construction of a landscape restoration strategy. Furthermore, we paid attention to the institutional web and actor constellation in the policy field, highlighting the conditions and circumstances around the Interministerial Commission between the Ministry of Environment and Energy and the Ministry of Agriculture and Livestock.

Because the commission is, at the point of writing, without an explicit agenda, future research may want to follow upon the further evolution of its mandate and scope of action. The outcome of the evaluation of the proposal for an action plan to implement the national Agro-Environmental Policy could provide an argument to sustain the commission, but the agenda of the new government will be crucial in this regard.

Also, because Costa Rica, as one interviewee mentioned, has a lot of ideas but limited funds, finance and coordination between various national and multilateral agencies will be key in rendering policy development effective. Research could build on the idea of so-called "habitat banks" to optimize the utilization of natural resources and biomass. Its mechanisms are similar to PES but it is different with respect to its sources for funding because it builds on revenues from business models instead of tax flows. These could be used for restoration and for the construction of green infrastructure related to mitigation and adaptation to achieve climate smart and, therefore, resilient landscape management. Costa Rica could thus, once again, establish itself as a real-world laboratory and provide for useful experiences for the rest of Latin America and other regions of the world to observe opportunities 
and challenges of a green transformation, particularly when they relate to climate-smart agriculture and the linkages between forest protection, ecosystem services, and agricultural productivity.

Responses to this article can be read online at: http://www.ecologyandsociety.org/issues/responses. $\mathrm{php} / 10476$

\section{Acknowledgments:}

This article is a result of the collaborative research project "Green Transformations in the Global South (GreeTS): opening the blackbox of a pro-active state and the management of sustainability trade-offs in Costa Rica and Vietnam" (http://www. greets-project. org), which is funded through the initiative "Europe and Global Challenges" by the Volkswagen Foundation, Riksbankens Jubileumsfond, and Wellcome Trust.

\section{LITERATURE CITED}

Arriagada, R. A., P. J. Ferraro, E. O. Sills, S. K. Pattanayak, and S. Cordero-Sancho. 2012. Do payments for environmental services affect forest cover? A farm-level evaluation from Costa Rica. Land Economics 88(2):382-399. http://dx.doi.org/10.3368/ le.88.2.382

Arriagada, R. A., E. O. Sills, P. J. Ferraro, and S. K. Pattanayak. 2015. Do payments pay off? Evidence from participation in Costa Rica's PES program. Plos One 10(8):e0131544. http://dx.doi. org/10.1371/journal.pone.0131544

Baker, R. 2014. Facilitating indigenous involvement in REDD+: early engagement and consultation in Costa Rica. Bank Information Center, Washington, D.C., USA.

Contraloría General de la República. 2011. Informe acerca de los efectos del programa pago por servicios ambientales (PSA) implementado por el Estado Costarricense. Informe Nro. DFOEAE-08-2007. Contraloría General de la República, San José, Costa Rica. [online] URL: https://cgrfiles.cgr.go.cr/publico/ jaguar/sad_docs/2011/DFOE-AE-IF-08-2011.pdf

Forest Carbon Partnership Facility (FCPF). 2013. Emission reductions program idea mote (ER-PIN). Template v.4. February 15, 2013. Forest Carbon Partnership Facility, Washington, D.C., USA. [online] URL: https://www.forestcarbonpartnership.org/ sites/fcp/files/2013/Costa $\% 20$ Rica $\% 20$ FCPF $\% 20$ ER $\% 20$ PIN $\% 20$ revised $\%$ 20February $\% 2015 \% 202013$.pdf

Fondo Nacional de Financiamiento Forestal (FONAFIFO). 2018. Sustainable biodiversity fund (SBF). Fondo Nacional de Financiamiento Forestal, San José, Costa Rica[online] URL: https://www.fonafifo.go.cr/en/conozcanos/proyectos-actuales/

German Advisory Council on Global Change (WBGU). 2011. World in transition: a social contract for sustainability. Summary for policy-makers. German Advisory Council on Global Change, Berlin, Germany. [online] URL: https://www.wbgu.de/fileadmin/ user_upload/wbgu.de/templates/dateien/veroeffentlichungen/ hauptgutachten/jg2011/wbgu jg2011 en.pdf
Gertenbach, W. P. D. 1983. Landscapes of the Kruger National Park. Koedoe 26(1):9-121. http://dx.doi.org/10.4102/koedoe. $\underline{\mathrm{v} 26 \mathrm{i} 1.591}$

Global Environmental Facility (GEF). 2005. Project executive summary: mainstreaming market-based instruments for environmental management. Global Environmental Facility, World Bank, Washington, D.C., USA. [online] URL: http://documents. worldbank.org/curated/en/412941468032708713/ pdf/368490CR0P098810Summary0WP01PUBLIC1.pdf

Intergovernmental Panel on Climate Change (IPCC). 2000. Special report on land use, land-use change, and forestry. Intergovernmental Panel on Climate Change, Geneva, Switzerland. [online] URL: https://www.ipcc.ch/pdf/specialreports/spm/srl-en.pdf

International Union for Conservation of Nature (IUCN). 2012. Landscape restoration movement approaches 50 million hectares with El Salvador and Costa Rica commitments. International Union for Conservation of Nature, Gland, Switzerland. [online] URL: https://www.iucn.org/content/landscape-restoration-movementapproaches-50-million-hectares-el-salvador-and-costa-rica

Jadin, I., P. Meyfroidt, and E. F. Lambin. 2016. International trade, and land use intensification and spatial reorganization explain Costa Rica's forest transition. Environmental Research Letters 11:035005. http://dx.doi.org/10.1088/1748-9326/11/3/035005

Lambin, E. F., B. L. Turner, H. J. Geist, S. B. Agbola, A. Angelsen, J. W. Bruce, O. T. Coomes, R. Dirzo, G. Fischer, C. Folke, P. S. George, K. Homewood, J. Imbernon, R. Leemans, X. Li, E. F. Moran, M. Mortimore, P. S. Ramakrishnan, J. F. Richards, H. Skånes, W. Steffen, G. D. Stone, U. Svedin, T. A. Veldkamp, C. Vogel, and J. Xu. 2001. The causes of land-use and land-cover change: moving beyond the myths. Global Environmental Change 11(4):261-269. http://dx.doi.org/10.1016/S0959-3780(01)00007-3

Lapola, D. M., R. Schaldach, J. Alcamo, A. Bondeau, J. Koch, C. Koelking, and J. A. Priess. 2010. Indirect land-use changes can overcome carbon savings from biofuels in Brazil. Proceedings of the National Academy of Sciences 107(8):3388-3393. http://dx. doi.org/10.1073/pnas.0907318107

Lederer, M., L. Wallbott, and F. Urban. 2019. Green transformations and state bureaucracy in the global south. In R. Fouquet, editor. Handbook on green growth. Edward Elgar, Cheltenham, UK.

Ministry of Environment and Energy (MINAE). 2016. Forest reference emission levellforest reference level. Submission to the UNFCCC Secretariat for technical review according to Decision 13/CP. 19. Ministry of Environment and Energy, San José, Costa Rica. [online] URL: https://redd.unfccc.int/files/2016 submission frel costa rica.pdf

Ministry of Environment and Energy (MINAE). 2017. Plan de implementación de la estrategia nacional REDD+ Costa Rica. Fondo Nacional de Financiamiento Forestal, San José, Costa Rica.

Miranda, M., I. T. Porras, and M. L. Moreno. 2003. The social impacts of payments for environmental services in Costa Rica. A quantitative field survey and analysis of the Virilla watershed. 
International Institute for Environment and Development, London, UK. [online] URL: http://pubs.iied.org/pdfs/9245IIED. pdf

Navarro, G. A., and V. Milla. 2017. Costa Rica y su marco actual de políticas agroambientales hacia un modelo exitoso de restauración en paisajes rurales. Policy Brief. CATIE, Turrialba, Costa Rica. [online] URL: https://www.politikwissenschaft.tudarmstadt.de/fileadmin/pg/arbeitsbereiche/ib/GreeTS/zzz.pdf

Navarro, G. A., and H. Thiel. 2007. On the evolution of the Costa Rican forestry control system. Verifor. Options for Forest Verification. Overseas Development Institute, London, UK. [online] URL: https://www.odi.org/sites/odi.org.uk/files/odiassets/publications-opinion-files/4450.pdf

Nielsen, T. D. 2016. From REDD+ forests to green landscapes? Analyzing the emerging integrated landscape approach discourse in the UNFCCC. Forest Policy and Economics 73:177-184. http:// dx.doi.org/10.1016/j.forpol.2016.09.006

Pagiola, S. 2008. Payments for environmental services in Costa Rica. Ecological Economics 65(4):712-724. http://dx.doi. org/10.1016/j.ecolecon.2007.07.033

Porras, I., D. N. Barton, A. Chacón-Cascante, and M. Miranda. 2013. Learning from 20 years of payments for ecosystem services in Costa Rica. International Institute for Environment and Development, London, UK. [online] URL: http://pubs.iied.org/ pdfs/16514IIED.pdf

Rosendal, G. K., and P. J. Schei. 2014. How may REDD+ affect the practical, legal and institutional framework for 'payment for ecosystem services' in Costa Rica? Ecosystem Services 9:75-82. http://dx.doi.org/10.1016/j.ecoser.2014.04.009

Sánchez-Azofeifa, G. A., A. Pfaff, J. A. Robalino, and J. P. Boomhower. 2007. Costa Rica's payment for environmental services program: intention, implementation, and impact. Conservation Biology 21(5):1165-1173. http://dx.doi.org/10.1111/ j.1523-1739.2007.00751.x

Schmitz, H. P., and B. Becker. 2013. From sustainable development to the green transformation - a rough guide. IDS briefing paper, Institute of Development Studies, Sussex, UK. [online] URL: https://opendocs.ids.ac.uk/opendocs/handle/123456789/2949

Scoones I., P. Newell, and M. Leach. 2015. The politics of green transformations: pathways to sustainability. Routledge, Abingdon, UK.

Sylvester, O., A. G. Segura, and I. J. Davidson-Hunt. 2016. The protection of forest biodiversity can conflict with food access for indigenous people. Conservation and Society 14(3):279-290. http://dx.doi.org/10.4103/0972-4923.191157

The REDD Desk. 2014. Actors. Global Canopy, Oxford, UK. [online] URL: http://theredddesk.org/countries/costa-rica/actors? page $=1$

The REDD Desk. 2018. REDD+ executive committee. Global Canopy, Oxford, UK. [online] URL: http://theredddesk.org/ countries/actors/redd-executive-committee-costa-rica

Turnhout, E., A. Gupta, J. Weatherley-Singh, M. J. Vijge, J. de Koning, I. J. Visseren-Hamakers, M. Herold, and M. Lederer.
2017. Envisioning REDD+ in a post-Paris era: between evolving expectations and current practice. WIREs Climate Change 8(1): e425. http://dx.doi.org/10.1002/wcc.425

Wallbott, L., and E. M. Florian-Rivero. 2018. Forests, rights and development in Costa Rica: a political ecology perspective on indigenous peoples' engagement in REDD+. Conflict, Security and Development 18(6):493-519. https://doi.org/10.1080/146788$\underline{02.2018 .1532643}$

World Bank. 2000. Costa Rica: forest strategy and the evolution of land use. Summary. World Bank, Washington, D.C., USA. [online] URL: http://lnweb90.worldbank.org/oed/oeddoclib.nsf/ DocUNIDViewForJavaSearch/A25EFCF3220878D585256970007AC9EE

World Bank. 2015. Costa Rica improves the efficiency of its payment for environmental services program. World Bank, Washington, D.C., USA. [online] URL: http://www.worldbank. org/en/results/2015/12/16/costa-rica-improves-the-efficiency-of-itspayment-for-environmental-services-program 